\title{
DESCRIPCIÓN BLOQUEO PLEXO BRAQUIAL ECOGUIADO MEDIANTE ABORDAJE INFRACLAVICULAR EN ESPACIO COSTOCLAVICULAR Y LAS ALTERACIONES DE PERFUSIÓN REGIONAL SECUNDARIAS
}

\author{
Nieuwveld Daniela ${ }^{1}$, Mojica Viviana ${ }^{2}$, Herrera Ana ${ }^{2}$, Pomés Jaume ${ }^{3}$, \\ Prats Alberto ${ }^{4}$, Sala-Blanch Xavier ${ }^{5}$ \\ 1 Anestesiologo Complejo asistencial Dr. Víctor Ríos Ruiz, Los Angeles. Master Anestesia Regional Basa. \\ Master Anestesia Regional Basada en Anatomía Universitat de Barcelona. \\ Radiológo. Sección de Radiología musculosquelética. Hospital Clinic. Universitat de Barcelona. \\ Catedrático Anatomía Facultad de Medicina. Universitat de Barcelona. \\ Anestesiologo. Hospital Clinic. Profesor Asociado de Anatomía. Facultad de Medicina. Universitat de B.
}

Introducción: El espacio costoclavicular es un buen acceso al plexo braquial, por la superficialidad y agrupación de los fascículos, laterales a la arteria axilar. Accediendo en plano, de medial a lateral, evitamos la coracoides y, por su dirección, a los vasos y pleura. Tradicionalmente evaluamos los bloqueos regionales con respuestas sensitivas y motoras, no obstante, el bloqueo simpático también es cuantificable.

Objetivo General: Demostrar factibilidad y efectividad del bloqueo costoclavicular acceso medial a lateral, evaluando el bloqueo simpático; mediante flujo humeral, índice de perfusión y temperatura; junto a clásicos parámetros sensitivos y motores.

Material y Métodos: Primera fase, punción ecoguiada de $20 \mathrm{ml}$ de medio de contraste en cadáver y obtención de imágenes mediante tomografía axial computarizada, posteriormente se congela cadáver a $-20^{\circ}$ durante $48 \mathrm{~h}$ para obtener secciones sagitales de la pieza anatómica, observaremos si la distribución es la adecuada. Segunda fase clínica, 11 pacientes sometidos a cirugía sobre miembro superior; mediremos flujo arteria humeral mediante doppler a dos centímetros sobre pliegue del codo, temperatura con termómetro cutáneo palmar, e índice de perfusión con pulsioximetro en el pulgar; una vez realizado el bloqueo con $20 \mathrm{ml}$ de mepivacaína al 1,5\% será medida la respuesta motora, sensitiva y simpática (a través de temperatura e índice de pulsatilidad), a los 5,10, 15 y 25 minutos de la realización del bloqueo. Una vez instaurado repetiremos la medición de flujo arteria humeral.

Resultados: Al realizar ecografía en cadáver ob- servamos la disposición lateral a la arteria axilar de los fascículos lateral, medial y posterior del plexo braquial; se realizó el acceso sin dificultades, ubicando la punta de la aguja al centro del paquete vasculonervioso, evidenciándose una adecuada distribución de medio de contraste tras la inyeccion. Posteriormente en la reconstrucción digital de la tomografía y en las secciones sagitales de las piezas anatómicas, observamos que se alcanzaron territorios supraclavicular e infraclavicular, desde C5 a T2. En la fase clínica, el bloqueo fue efectivo en el $91 \%$ de los pacientes a los 25 minutos. El flujo arterial humeral aumentó significativamente de 108 a $188 \mathrm{ml} / \mathrm{min}$ (p $=0,05)$ tras el bloqueo. La temperatura cutánea $\left(32,1 \pm 2{ }^{\circ} \mathrm{C}\right.$ a $\left.32,8 \pm 9{ }^{\circ} \mathrm{C} ; \mathrm{p}=0,03\right)$ e índice de perfusión ( $4 \pm 3$ a $9 \pm 5 ; \mathrm{p}=0,003$ ) aumentaron significativamente a los 5 minutos del bloqueo, sin variación en extremidad contralateral.

Conclusiones: La técnica propuesta es anatómicamente factible y clínicamente eficaz. Los fascículos se agrupan laterales a la arteria, diferenciándose de abordajes clásicos, y una inyección

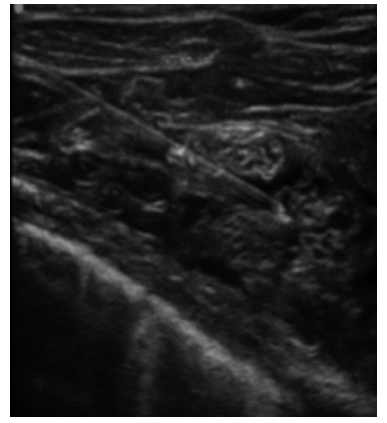

Figura 1. 
central de $20 \mathrm{ml}$ de anestésico logra rodearlos. En 1973, Raj y col describen el abordaje infraclavicular medial a lateral, similar al descrito por nosotros; sin embargo, la dirección de la aguja es ligeramente más craneal, favoreciendo la distribución del anestésico local al espacio infraclavicular y supraclavicular. Las alteraciones secun- darias al bloqueo simpático son objetivables con mediciones de flujo humeral, índice de perfusión y temperatura, correlacionándose precozmente con la instauración de bloqueo motor y sensitivo. Dada la simplicidad y continuidad en la medición del IP, consideramos sería un parámetro a tener en cuenta en el futuro. 